\title{
Physicochemical Characteristics of Snail as Affected by Processing Methods, Temperatures and Storage Days
}

\author{
I. Iwanegbe ${ }^{1^{*}}$, G. U. Emelue ${ }^{2}$, and J. U. Obaroakpo ${ }^{1}$ \\ ${ }^{1}$ Department of Food Technology, Auchi Polytechnic, Auchi, Edo State, Nigeria. \\ ${ }^{2}$ Department of Forestry and Wildlife, Faculty of Agriculture, University of Benin, PMB 1154,
}

Benin City, Nigeria.

\begin{abstract}
Authors' contributions
This work was carried out in collaboration among all authors. Author II designed the study, performed the statistical analysis, wrote the protocol, and wrote the first draft of the manuscript. Authors GUE and JUO managed the analyses of the study. Author JUO managed the literature searches. All authors read and approved the final manuscript.

Article Information

DOI: $10.9734 / A R R B / 2018 / v 30 i 530023$

Editor(s):

(1) Dr. Jean-Marie Exbrayat, Professor, Universite Catholique de Lyon, France. (2) Dr. George Perry, Dean and Professor of Biology, University of Texas at San Antonio, USA.

Reviewers:

(1) Dr. O. A. Adedokun, Federal University of Technology, Nigeria. (2) Adeyeye, Samuel Ayofemi Olalekan, Ton Duc Thang University, Ho Chi Minh City, Vietnam. Complete Peer review History: http://www.sdiarticle3.com/review-history/47022
\end{abstract}

Original Research Article

Received 03 December 2018

Accepted 12 February 2019

Published 13 March 2019

\begin{abstract}
This study investigated the effect of processing methods, temperature and storage days on the physico-chemical characteristics of snail meat products. Four different treatments were carried out; unseasoned fried (USF), seasoned fried (SF), seasoned oven- dried (SOD) and seasoned smokedried (SSD) snail meat products and were stored under room, fridge and freezer storage conditions; physico-chemical determination and analysis of variance were carried out. The results showed that the highest crude protein was obtained in the seasoned smoke-dried product (76.87\%), followed by seasoned oven-dried product $(75.80 \%)$, next was seasoned fried $(70.15 \%)$ and the least was unseasoned fried product $(68.57 \%)$. The highest ash value was seen in seasoned smoke-dried product $(4.84 \%)$, followed by seasoned oven-dried $(4.313 \%)$ and the least was unseasoned-fried product $(3.933 \%)$. The highest energy values were observed in the fried products $(1497.67 \mathrm{KJ} / 100 \mathrm{~g}$ seasoned fried and $1490.53 \mathrm{KJ} / 100 \mathrm{~g}$ unseasoned-fried). The highest iron value $(16.47 \mathrm{mg} / 100 \mathrm{~g})$
\end{abstract}


obtained was from seasoned smoke-dried product. Seasoned smoke-dried product was significantly different from other products and it had the highest mineral content. Seasoned oven-dried snail meat product had the lowest $\mathrm{pH}$ values $6.0,7.17$ and 6.29 for $0-5$ days, 10-20 days and 25- 30 days storage respectively. This was followed by seasoned smoke-dried product having 6.68, 7.81 and 6.56 at 0-5 days, $10-20$ days and 25-30 days respectively. The observed low $\mathrm{pH}$ in seasoned products could be ascribed to the effect of the seasonings; this is an indication of better shelf stability. It was observed that the combine effect of seasonings, smoke-drying and cold storage help to extend the shelf life of snail meat.

Keywords: Processing; temperature; snail; products; seasoned.

\section{INTRODUCTION}

The land snails, particularly the Archachatina marginata, are alternative and non-conventional animal protein source in Nigeria and some other parts of Africa. Snails are processed by different methods for consumption. The different processing methods include roasting, ovendrying, frying etc. However, Onyeike and Oguike [1] and Ojiako, et al. [2] reported that different processing methods including boiling and roasting, influence the proximate, mineral and toxicant composition of foods. Preservation extends the shelf life of meat sample. Also, it is regarded as any method of treatment of food material to prolong the length of time in which it retains its qualities and appearance. Preservation methods include freezing, thermal processing (dehydration e.g. oven drying and smoke-drying) and curing method by using chemical additives [3].

Smoke-drying of meat is a technique whereby meat is exposed directly to wood smoke which may be generated by a variety of methods. There are various substances in the smoke produced from wood which contribute to the flavour and the appearance of the smoke-dried meat product and this has certain preserving effect on the product [3]. The preserving effect of smoke is not very significant when storing the product without a cold chain. On the other hand, intensive or prolonged smoke-drying may considerably increase the shelf-life of the product, but it also has an unfavourable effect on flavour. Whereas a light smoke generally enhances the organoleptic properties of the product, intensive smoking has a negative effect on the quality, especially in the case of prolonged storage in which concentrated smoke compounds develop increasingly unpleasant flavour.

In modern meat processing industries, beef, pork, lamb, veal and calf carcasses are chilled in chill cooler at temperature ranging from -4 to $0^{\circ} \mathrm{C}$. Chilling storage is generally regarded to be storage at temperature not far above freezing. The refrigerated storage of meat and meat products at $5^{\circ} \mathrm{C}-10^{\circ} \mathrm{C}$ is generally limited to relatively short periods, since deteriorative changes continue to occur. The major factors that influence the storage life of meat under refrigeration include the initial microbial load, temperature and humidity conditions during storage, the presence or absence of protective coverings, the species of animal involved, and the type of product being stored. Freezing as a preservation method is not a new process. It has long been recognized as an excellent means of meat preservation.

Snails are considered a delicacy in many countries and are staple part of the diet in parts of Asia where red meat and poultry are scarce sources of protein. In Nigeria, it is now accepted that the use of mini-livestock such as snails, rodents and other small livestock in the wild can substantially improve the living conditions of people in urban and rural areas by acting as a valuable source of protein supplement to diet as well as generating additional income [4].

The aim of this study was to investigate the effect of processing methods, temperature and storage days on the physico-chemical characteristics of snail meat products.

\section{MATERIALS AND METHODS}

\subsection{Source of Snails}

The snails used for this experiment were collected from Ekiuwa market in Edo State, Nigeria. A total of 150 adult snails (Archachatina marginata) with mean live weight of $346.85 \mathrm{~g}$, were used. They were transferred to University of Benin where they were processed.

\subsection{Removal of Meat from Shells}

Snails were fasted for 24 hours in order to empty their guts and to reduce contamination during processing. Then the snails were weighed and 
separated into meat, shell, waste and fluid. The meats were washed with alum to remove the slime and cut to uniform weight range of 50-55 g.

\subsection{Application of Pickle in the Preservation of Fresh Snail Meat}

Meat may be preserved by dry curing or with a pickling solution. The ingredients used in curing and pickling are sodium nitrate, sodium nitrite, sodium chloride, sugar, citric acid or vinegar etc. Various methods are used: the meat may be mixed with dry ingredients; it may be soaked in pickling solution; pickling solution may be pumped or injected into the flesh; or a combination of these methods may be used.

In this study, snails were cured in a prepared pickle solution containing $1.5 \%$ salt, $1.5 \%$ sugar, $0.5 \%$ thyme, $0.30 \%$ nutmeg, $0.30 \%$ ginger, $1.50 \%$ red pepper, $0.05 \%$ sodium sorbate, $0.05 \%$ sodium tripolyphosphate, $0.50 \%$ curry, $1.50 \%$ onion (Table 1) for 24hours in refrigeration temperature, before processing snails (frying, smoke-drying and oven-drying). However, the control was devoid of spices before frying.

\subsection{Processing Methods}

\subsubsection{Smoke-drying}

Pickle cured snail meat were skewed and smoke-dried at $80^{\circ} \mathrm{C}$ for 2 hours 15 minutes in a smoking kiln at Kilishi factory, Ekenwan Campus, Benin City, Nigeria. Each snail meat was spread out with stick in a traditional bush meat processing manner to increase the surface area of the meat exposed to smoke and heat. The meat samples were spread on racks in the smoking kiln to ensure uniform drying of the individual product. Initial weights of snail meat prior to smoke-drying were taken and weights after smoking were equally recorded.

\subsubsection{Frying}

Pickle cured snails were fried at $170^{\circ} \mathrm{C}$ for 30 minutes in a deep pan fryer with Soya oil (cholesterol free). 15 minutes into frying, meats were removed from oil, allowed to cool and weighed.

\subsubsection{Oven-drying}

Pickle cured snail meats were oven-dried at $90^{\circ} \mathrm{C}$ for 4 hours $30 \mathrm{~min}$ using table electric oven. The racks inside the oven were wrapped with foil paper before the meats were spread on them. At every 45 minutes interval, meats were removed, allowed to cool and weighed.

\subsection{Packaging}

Snail meat products were allowed to cool before packaging all the products including seasoned smoke-dried product that was skewed. All products were sealed in low density cellophanes with the use of sealing machine.

\subsection{Storage Temperatures}

In this experiment, three storage temperatures were used.

-Room temperature $\left(28.5^{\circ} \mathrm{C}\right)$

- Refrigeration temperature $\left(9.5^{\circ} \mathrm{C}\right)$

-Freezer temperature $\left(-12.5^{\circ} \mathrm{C}\right)$

\subsection{Storage Period}

Snail meat products were stored for total duration of 30 days and meat samples were withdrawn for analyses as follows.

- 0 day (control)

-5 days

-10 days

-15 days

-20 days

-25 days

- 30 days

\subsection{Analytical Methods}

Moisture content was determined by drying an accurately weighed sample of minced samples in an oven at $105 \pm 2^{\circ} \mathrm{C}$ for 3 hours. The ash content was obtained by heating the sample for 3 hours at $550^{\circ} \mathrm{C}$. Fat was extracted according to the acid hydrolysis method. The total nitrogen content was determined by the Kjeldahl method and was converted to crude protein content by multiplying by $6.25[5]$.

$\mathrm{pH}$ was determined on dispersion of two-gram sample in $10 \mathrm{ml}$ of distilled water while a pocket $\mathrm{pH}$ meter was used to take $\mathrm{pH}$ values.

\subsection{Data Analysis}

Data generated were subjected to analysis of Variance (ANOVA) to test significant variations $(P<0.05)$ among mean values obtained. Duncan's multiple range test was applied to indicate where significant differences $(P<0.05)$ occurred using Genstat statistical package 2005, $8^{\mathrm{TH}}$ edition (Genstat Procedure Library Release PL16). 
Table 1. Pickle formulation

\begin{tabular}{lll}
\hline Ingredients & Percentage (\%) & Weight (g) \\
\hline Sugar & 1.50 & 45 \\
Salt & 1.50 & 45 \\
Thyme & 0.50 & 15 \\
Nutmeg & 0.30 & 9 \\
Ginger & 0.30 & 9 \\
Red pepper & 1.50 & 45 \\
Sodium sorbate & 0.05 & 1.5 \\
Sodium tripolyphosphate & 0.05 & 1.5 \\
Curry & 0.5 & 15 \\
Onion & 1.50 & 45 \\
Water & 91.85 & 2755.5 \\
Total & $100 \%$ & $3000 \mathrm{~g}$ \\
\hline
\end{tabular}

\section{RESULTS AND DISCUSSION}

\subsection{Chemical Composition of Snail Meat Products}

The result of this study showed that the crude protein, fat, moisture, ash, fiber and carbohydrate of raw snail, were $16.69 \%, 4.87 \%, 64.03 \%$, $3.78 \%, 3.47 \%$ and $6.89 \%$ respectively. The value of crude protein $(16.69 \%)$ obtained is similar to the result $(16.82 \%)$ of [6]. The moisture content $(64.03 \%)$ obtained was similar to the result (63.1\%) of Malik et al. (2011) but different from the work of Okonkwo and Anyaene [6] who had $79.48 \%$. The crude fiber $(3.47 \%)$ obtained was not different from the result $(3.45 \%)$ reported by Omoyakhi and Osinowo [7].

Analysis of variance showed significant difference $\left(P<0.001^{\prime}\right)$ in the chemical composition of the products based on treatment applied (Table 2). There was significant difference $(P<0.05)$ in the crude protein content among the products. The highest crude protein was obtained in the seasoned smoke-dried product $(76.87 \%)$, followed by oven-dried product $(75.80 \%)$, next was seasoned fried $(70.15 \%)$ and the least was unseasoned fried product $(68.57 \%)$. The high protein value in seasoned smoke-dried product demonstrates that smoke component has preservative influence on crude protein due to reduction effect on $\mathrm{pH}$ by smoke components. Besides, wood smoke contains pyroligenous acid which may have added preservative effect on smoke-dried meat. Akhter et al. [8] reported that protein value of smoked meat $(77.92 \%)$ product was significantly $(P<0.05)$ higher than crude protein of meat obtained from other processing methods. This could be attributed to lowering effect of $\mathrm{pH}$ by smoke components.
In terms of moisture content the different processing methods drastically reduced the moisture content of the raw snail meat. Iwanegbe, et al. [9] reported that processing methods have the potential of removing moisture from samples. Chima and Akobundu [10] reported that moisture content of sample decreases significantly $(P<0.05)$ with processing. The seasoned oven-dried product with the lowest moisture content was significantly different $(P<0.05)$ from other products. Smoke-dried product was significantly different $(P<0.05)$ from other products in terms of ash content. The highest ash value was seen in seasoned smokedried product $(4.84 \%)$, followed by seasoned oven-dried $(4.313 \%)$ and the least was unseasoned-fried (3.933\%) although, Adegbite, et al. [11] reported ash content of $4.23 \%$ for snail of 6-12 months old.

For fat content, seasoned-fried (4.920\%) and unseasoned-fried $(5.033 \%)$ snail products were significantly different $(P<0.05)$ from smoke-dried $(2.513 \%)$ and oven-dried products $(2.57 \%)$. The high values recorded in the fried products could be attributed to oil absorption by the meat.

There was significant difference $(P<0.05)$ in carbohydrate content among all the products. The highest carbohydrate value was seen in unseasoned-fried product $(8.16 \%)$ and the lowest was smoke-dried product (1.86\%).

There was significant difference $(P<0.05)$ among the products in terms of crude fiber. However, the unseasoned-fried product had the highest fiber $(3.77 \%)$ content. The highest energy values were seen in the fried products $(1497.67 \mathrm{KJ} / 100$ $\mathrm{g}$ seasoned fried and $1490.53 \mathrm{KJ} / 100 \mathrm{~g}$ unseasoned-fried). Although, all the products energy values ranged from 1431.40 - 1497.67 $\mathrm{KJ} / 100 \mathrm{~g}$, these values are lower than the energy 
$(1726-1740 \mathrm{KJ} / 100 \mathrm{~g})$ reported by Engman, ret al. [12] but greater than the values reported by Oduro, et al. [13] who reported $390.92-435.97$ $\mathrm{KJ} / 100 \mathrm{~g}$. The energy values obtained in this study shows that snail meat could provide appreciable amount of calories in diet.

The results of this work showed that raw snail has Calcium (124.32 mg/100 g), iron $(2.27 \mathrm{mg} / 100 \mathrm{~g})$, Phosphorus (21.97 mg /100 g), Magnesium (23.95 mg/100 g), Copper (1.08 $\mathrm{mg} / 100 \mathrm{~g})$ and potassium $(26.7 \mathrm{mg} / 100 \mathrm{~g})$ contents. The values obtained are not different from the result of Malik et al. (2011) who reported $\mathrm{Ca}(126 \mathrm{mg} / 100 \mathrm{~g}), \mathrm{Fe}(2.29 \mathrm{mg} / 100 \mathrm{~g}), \mathrm{P}(22.9$ $\mathrm{mg} / 100 \mathrm{~g}), \mathrm{Mg}(25.1 \mathrm{mg} / 100 \mathrm{~g})$ and $\mathrm{Cu}(1.03$ $\mathrm{mg} / 100 \mathrm{~g}$ ). Adeola, et al. [14] reported Calcium $(187 \mathrm{mg} / 100 \mathrm{~g})$ and potassium $(25.6 \mathrm{mg} / 100 \mathrm{~g})$ for raw snail. The minerals for processed snail range from $146.3 \mathrm{mg} / 100 \mathrm{~g}-165.7 \mathrm{mg} / 100 \mathrm{~g}$ for calcium, $14.07-16.47 \mathrm{mg} / 100 \mathrm{~g}$ iron, $183.0-235.0$ $\mathrm{mg} / 100 \mathrm{~g}$ phosphorus, $74.63-104.23 \mathrm{mg} / 100 \mathrm{~g}$ copper, $305-386.3 \mathrm{mg} / 100 \mathrm{~g}$ potassium and $57.63-64.63 \mathrm{mg} / 100 \mathrm{~g}$ magnesium.

From the analysis of variance the seasoned smoke-dried product was significantly different $(P<0.05)$ from other products and had the highest mineral content. The value obtained for $P$ $(235.0 \mathrm{mg} / 100 \mathrm{~g})$ was not different from the value $(238.0 \mathrm{mg} / 100 \mathrm{~g})$ obtained by Kalio, et al. [15]. Phosphorus and potassium are important in human and animal nutrition. Phosphorus is used for normal development and maintenance of bones and teeth, cell activity, normal acid-base balance of blood, muscle activity, metabolism of carbohydrate and fat.

The highest iron value obtained $(16.47 \mathrm{mg} / 100 \mathrm{~g})$ was from seasoned smoke-dried product. This is close to the result $(12.2 \mathrm{mg} / 100 \mathrm{~g})$ obtained by [16]. However, the value obtained was not different from $16.1 \mathrm{mg} / 100 \mathrm{~g}$ reported by Kalio, et al. [15]. Wosu [16] reported that iron content of snail varies from one locality to another depending on mineral content of the soil in which these snails are raised. Iron is good for bone and teeth formation as well as for haemoglobin of the red blood cells. Cobalt (Co) was not detected. According to Fagbuaro, et al. [17] the nondetection of lead and cobalt confirm that none of the snail had been exposed to any sort of pollution.

\section{2 pH Changes of Snail Meat Products}

The analysis of variance showed that there was significant difference $(P<0.001)$ in the main and interactive effects in $\mathrm{pH}$ values of the different snail meat products based on treatments (Processing methods, storage conditions and storage days).

The average $\mathrm{pH}$ value of raw snail washed without alum was 7.02 while raw snail washed with alum had an ultimate $\mathrm{pH}$ of 7.3. This value agreed closely with the work of [6] who reported $\mathrm{pH}$ value of 7.4 , this according to them is due to the basicity of potassium alum used for washing the foot, which tends to raised $\mathrm{pH}$ value.

Table 3 showed the main effect of processing methods on the $\mathrm{pH}$ of products. There was significant difference $(P<0.05)$ in the different products stored for 0-5 days, $10-20$ days and 2530 days. Seasoned oven-dried snail meat product (412) had the lowest $\mathrm{pH}$ values 6.0, 7.17 and 6.29 for $0-5$ days, $10-20$ days and $25-30$ days storage respectively. This was followed by seasoned smoke-dried product having 6.68, 7.81 and 6.56 respectively. Moreover, it was observed that seasoned products had lower $\mathrm{pH}$ than the unseasoned product, an indication of better shelf stability of the seasoned products. This could be attributed to the presence of salt and other curing ingredients which altered the $\mathrm{pH}$ of the seasoned products, thereby limiting the growth of spoilage organisms. The result of this study showed that the interactive effect of salt and other spices inclusion in the seasoned snail meat products lowered the $\mathrm{pH}$ thereby ensuring shelf stable products.

Table 4 showed the effect of storage conditions on $\mathrm{pH}$ of products. There was significant difference $(P<0.05)$ between products under room storage (7.20) and products under cold storage (fridge 6.61 and freezer 6.05) at 5 days. Products under room and fridge storage could not last beyond 5 days and 20 days respectively. Table 5 also showed significant difference $(\mathrm{P}<0.05)$ in the $\mathrm{pH}$ of products stored for 10 days (7.51), 15 days (8.22) and 20 days (8.59).

Table 6 showed the $\mathrm{pH}$ values of the interaction between processing methods and storage periods. The $\mathrm{pH}$ values of the snail meat products significantly $(P<0.05)$ increased with the storage days (0-5 and 10-20) but with insignificant $(P>0.05)$ decline at 25 days. Seasoned oven-dried product had the lowest $\mathrm{pH}$ values of $5.76,6.69$ and 6.26 for $0-5$ days, $10-20$ days and 25-30 days storage period respectively. This was followed by seasoned smoke-dried product $(6.40,7.54$ and 6.49$)$. The unseasoned- 
fried product (control) had the highest $\mathrm{pH}$ values at 5 days (7.98), 20 days (9.77) and 25 days (8.33) storage. This high value was responsible for the short shelf life of the unseasoned fried product (control). Kiers, et al. [18] reported that the increase in $\mathrm{pH}$ value during storage is due to the degradation of protein.

Table 2. Means for chemical composition of snail meat products

\begin{tabular}{llllll}
\hline $\begin{array}{l}\text { Parameter } \\
\text { seasoned }\end{array}$ & $\begin{array}{l}\text { Unseasoned } \\
\text { fried (311) }\end{array}$ & fried (312) & $\begin{array}{l}\text { Seasoned } \\
\text { oven-dried (412) }\end{array}$ & $\begin{array}{l}\text { Seasoned } \\
\text { smoke-dried (512) }\end{array}$ & LSD \\
\hline Protein(\%) & $68.567^{\mathrm{d}}$ & $70.150^{\mathrm{c}}$ & $75.803^{\mathrm{b}}$ & $76.867^{\mathrm{a}}$ & 0.1770 \\
Moisture (\%) & $10.543^{\mathrm{a}}$ & $10.050^{\mathrm{b}}$ & $9.563^{\mathrm{c}}$ & $10.467^{\mathrm{a}}$ & 0.0773 \\
Ash (\%) & $3.933^{\mathrm{d}}$ & $3.963^{\mathrm{c}}$ & $4.313^{\mathrm{b}}$ & $4.837^{\mathrm{a}}$ & 0.0129 \\
Fat (\%) & $5.033^{\mathrm{a}}$ & $4.920^{\mathrm{a}}$ & $2.570^{\mathrm{b}}$ & $2.513^{\mathrm{b}}$ & 0.1227 \\
Crude fiber (\%) & $3.767^{\mathrm{a}}$ & $3.677^{\mathrm{b}}$ & $3.490^{\mathrm{c}}$ & $3.453^{\mathrm{a}}$ & 0.0179 \\
Carbohydrate $(\%)$ & $8.157^{\mathrm{a}}$ & $7.240^{\mathrm{b}}$ & $4.260^{\mathrm{c}}$ & $1.863^{\mathrm{d}}$ & 0.2681 \\
Energy $(\mathrm{KJ} / 100 \mathrm{~g})$ & $1490.53^{\mathrm{b}}$ & $1497.67^{\mathrm{a}}$ & $1456.17^{\mathrm{c}}$ & $1431.40^{\mathrm{d}}$ & 2.813 \\
$\mathrm{Ca}(\mathrm{mg} / 100 \mathrm{~g})$ & $146.3^{\mathrm{c}}$ & $153.7^{\mathrm{bc}}$ & $156.7^{\mathrm{b}}$ & $165.7^{\mathrm{a}}$ & 8.22 \\
$\mathrm{Fe}(\mathrm{mg} / 100 \mathrm{~g})$ & $14.07^{\mathrm{d}}$ & $14.70^{\mathrm{c}}$ & $15.20^{\mathrm{b}}$ & $16.47^{\mathrm{a}}$ & 0.38 \\
$\mathrm{P}(\mathrm{mg} / 100 \mathrm{~g})$ & $183.0^{\mathrm{d}}$ & $196.3^{\mathrm{c}}$ & $204.7^{\mathrm{b}}$ & $235.0^{\mathrm{a}}$ & 7.33 \\
$\mathrm{Cu}(\mathrm{mg} / 100 \mathrm{~g})$ & $74.63^{\mathrm{d}}$ & $87.0^{\mathrm{c}}$ & $96.67^{\mathrm{b}}$ & $104.23^{\mathrm{a}}$ & 4.05 \\
$\mathrm{~K}(\mathrm{mg} / 100 \mathrm{~g})$ & $305^{\mathrm{d}}$ & $327.3^{\mathrm{c}}$ & $358^{\mathrm{b}}$ & $386.3^{\mathrm{a}}$ & 10.98 \\
$\mathrm{Mg}(\mathrm{mg} / 100)$ & $57.63^{\mathrm{c}}$ & $60.55^{\mathrm{b}}$ & $62.97^{\mathrm{a}}$ & $64.63^{\mathrm{a}}$ & 2.29 \\
\hline \multicolumn{5}{c}{ Means with same superscript along the row are not significantly differently $(P>0.05)$} &
\end{tabular}

Table 3. pH of snail meat products (processing methods)

\begin{tabular}{llllll}
\hline \multicolumn{5}{c}{ Treatments (processing methods) } \\
\hline $\begin{array}{l}\text { Storage } \\
\text { days }\end{array}$ & $\begin{array}{l}\text { Unseasoned/ } \\
\text { fried }\end{array}$ & $\begin{array}{c}\text { Seasoned/ } \\
\text { fried }\end{array}$ & $\begin{array}{l}\text { Seasoned/ } \\
\text { oven-dried }\end{array}$ & $\begin{array}{l}\text { Seasoned/ } \\
\text { smoke-dried }\end{array}$ & LSD \\
\hline $0-5$ & $7.711^{\mathrm{a}}$ & $6.811^{\mathrm{a}}$ & $6.000^{\mathrm{d}}$ & $6.689^{\mathrm{c}}$ & 0.0839 \\
$10-20$ & $9.147^{\mathrm{a}}$ & $8.046^{\mathrm{b}}$ & $7.170^{\mathrm{d}}$ & $7.817^{\mathrm{c}}$ & 0.1317 \\
$25-30$ & $8.226^{\mathrm{a}}$ & $6.708^{\mathrm{b}}$ & $6.290^{\mathrm{d}}$ & $6.563^{\mathrm{c}}$ & 0.0207 \\
\hline \multicolumn{5}{c}{ Means within storage day bracket having same superscript are not significantly different $(P>0.05)$}
\end{tabular}

Means within storage day bracket having same superscript are not significantly different $(P>0.05)$

Table 4. pH of snail meat products (storage conditions)

\begin{tabular}{|c|c|c|c|c|}
\hline \multicolumn{5}{|c|}{ Treatments(storage conditions) } \\
\hline Storage days & $\operatorname{Room}\left(28.5^{\circ} \mathrm{C}\right)$ & Fridge $\left(9.5^{\circ} \mathrm{C}\right)$ & Freezer(-12.5 $\mathrm{C})$ & LSD \\
\hline $0-5$ & $7.207^{\mathrm{a}}$ & $6.617^{\mathrm{b}}$ & $6.058^{b}$ & 0.0727 \\
\hline $10-20$ & - & 9.129 & 6.961 & .0927 \\
\hline $25-30$ & - & - & - & - \\
\hline
\end{tabular}

Table 5. pH of snail meat products (storage days)

\begin{tabular}{llc}
\hline Storage days & Means values & LSD \\
\hline 0 & 6.525 & 0.0593 \\
5 & 7.081 & \\
10 & $7.518^{\mathrm{c}}$ & 0.1141 \\
15 & $8.220^{\mathrm{b}}$ & \\
20 & $8.595^{\mathrm{a}}$ & \\
25 & 7.022 & 0.014 \\
30 & & \\
\end{tabular}


Table 6. Effect of storage on $\mathrm{pH}$ changes of snail meat

\begin{tabular}{|c|c|c|c|c|c|c|c|}
\hline \multicolumn{8}{|c|}{ Storage period (days) } \\
\hline Products & 0 & 5 & 10 & 15 & 20 & 25 & 30 \\
\hline 311 & $7.433^{b}$ & $7.989^{\mathrm{a}}$ & $8.278^{\mathrm{d}}$ & $9.385^{b}$ & $9.778^{\mathrm{a}}$ & $8.333^{\mathrm{a}}$ & $8.120^{6}$ \\
\hline 312 & $6.500^{\mathrm{e}}$ & $7.122^{\mathrm{c}}$ & $7.557^{\text {gh }}$ & $7.945^{\mathrm{ef}}$ & $8.635^{\mathrm{c}}$ & $6.813^{\mathrm{c}}$ & $6.603^{\mathrm{d}}$ \\
\hline 412 & $5.767^{g}$ & $6.233^{\dagger}$ & $6.697^{\jmath}$ & $6.977^{\prime}$ & $7.837^{\dagger}$ & $6.313^{\dagger}$ & $6.266^{g}$ \\
\hline 512 & $6.400^{\mathrm{e}}$ & $6.978^{\mathrm{d}}$ & $7.540^{\mathrm{n}}$ & $7.782^{\text {tg }}$ & $8.130^{\mathrm{de}}$ & $6.630^{\mathrm{d}}$ & $6.496^{\mathrm{e}}$ \\
\hline SEM & & 417 & & & & 0.0096 & \\
\hline
\end{tabular}

Means within storage day bracket having same superscript along the row and down the column are not significantly different $(P>0.05)$.

$311=$ unseasoned fried, 312=seasoned fried, 412=seasoned oven-dried, 512=seasoned smoke-dried

Table 7. pH of snail meat products (storage conditions and storage days)

\begin{tabular}{llllllll}
\hline & \multicolumn{7}{c}{ Storage period (days) } \\
\hline Storage Condition & $\mathbf{0}$ & $\mathbf{5}$ & $\mathbf{1 0}$ & $\mathbf{1 5}$ & $\mathbf{2 0}$ & $\mathbf{2 5}$ & $\mathbf{3 0}$ \\
\hline Room $\left(28.5^{\circ} \mathrm{C}\right)$ & $6.525^{\mathrm{c}}$ & $7.883^{\mathrm{a}}$ & - & - & - & - & - \\
Fridge $\left(9.5^{\circ} \mathrm{C}\right)$ & $6.525^{\mathrm{c}}$ & $6.708^{\mathrm{b}}$ & $8.285^{\mathrm{c}}$ & $9.168^{\mathrm{b}}$ & $9.932^{\mathrm{a}}$ & - & - \\
Freezer $\left(-12.5^{\circ} \mathrm{C}\right)$ & $6.525^{\mathrm{c}}$ & $6.650^{\mathrm{b}}$ & $6.751^{\mathrm{e}}$ & $6.876^{\mathrm{e}}$ & $7.257^{\mathrm{d}}$ & 7.022 & 6.8717 \\
SEM & \multicolumn{2}{c}{0.0361} & & 0.0567 & & 0.0048 & \\
\hline
\end{tabular}

Means within storage day bracket having same superscript along the row and down the column are not significantly different $(P>0.05)$.

Table 8. pH of snail meat products (processing methods and storage conditions)

\begin{tabular}{|c|c|c|c|}
\hline Products & Fridge $\left(9.5^{\circ} \mathrm{C}\right)$ & Freezer $\left(-12.5^{\circ} \mathrm{C}\right)$ & $\operatorname{Room}\left(28.5^{\circ} \mathrm{C}\right)$ \\
\hline \multicolumn{4}{|l|}{ 0-5 days } \\
\hline 311 & $7.517^{b}$ & $7.483^{b c}$ & $8.133^{\mathrm{a}}$ \\
\hline 312 & $6.533^{\mathrm{e}}$ & $6.550^{\mathrm{e}}$ & $7.350^{\mathrm{C}}$ \\
\hline 412 & $5.817^{\mathrm{h}}$ & $5.817^{h}$ & $6.183^{\dagger}$ \\
\hline 512 & $6.417^{\mathrm{e}}$ & $6.500^{\mathrm{e}}$ & $7.150^{\mathrm{d}}$ \\
\hline SEM & 0.0511 & 0.0511 & 0.511 \\
\hline \multicolumn{4}{|c|}{$10-20$ days } \\
\hline 311 & $10.208^{\mathrm{a}}$ & $8.087^{\mathrm{d}}$ & - \\
\hline 312 & $9.267^{\mathrm{b}}$ & $6.824^{\mathrm{e}}$ & - \\
\hline 412 & $8.162^{d}$ & $6.178^{\dagger}$ & - \\
\hline 512 & $8.878^{\mathrm{C}}$ & $6.757^{\mathrm{e}}$ & - \\
\hline SEM & 0.0654 & 0.0654 & \\
\hline \multicolumn{4}{|c|}{ 25-30 days } \\
\hline 311 & - & $8.227^{\mathrm{a}}$ & - \\
\hline 312 & - & $6.708^{b}$ & - \\
\hline 412 & - & $6.290^{\mathrm{d}}$ & - \\
\hline 512 & - & $6.563^{\mathrm{c}}$ & - \\
\hline SEM & 0.0068 & & \\
\hline
\end{tabular}

Means within storage day bracket having same superscript along the row and down the column are not significantly different $(P>0.05)$.

$311=$ unseasoned fried, 312=seasoned fried, 412=seasoned oven-dried, 512=seasoned smoke-dried

Table 7 showed the changes in $\mathrm{pH}$ values of products due to the interaction between storage conditions and storage days. There was significant difference $(\mathrm{P}<0.05)$ between $\mathrm{pH}$ of products stored for $0-5$ days, $10-20$ days and 2530 days under the different storage conditions. Products under room storage increased significantly $(\mathrm{P}<0.05)$ in $\mathrm{pH}$ than snail meat products under cold storage from 0-5 days. Also, products under fridge (6.70) storage condition were not significantly $(P>0.05)$ different from snail meat under freezer (6.65) storage at 5 days. This implies that cold storage helps to control and stabilize $\mathrm{pH}$ of meat products thereby enhancing their shelf stability. Iwanegbe, et al. [9] reported that refrigeration extends shelf stability and prevent product deterioration. A significant increase $(P<0.05)$ was observed in the $\mathrm{pH}$ values of products under refrigerated storage from 10-20 days. 
Table 9. pH means of snail meat products (processing methods, storage days and storage conditions)

\begin{tabular}{|c|c|c|c|c|c|c|c|}
\hline \multicolumn{8}{|c|}{ Storage period(days) } \\
\hline Products storage conditions & $\begin{array}{ll}0 & \\
\end{array}$ & 5 & 10 & 15 & 20 & 25 & 30 \\
\hline 311 Freezer $\left(-12.5^{\circ} \mathrm{C}\right)$ & $7.433^{\mathrm{d}}$ & $7.533^{\mathrm{d}}$ & $7.703^{\text {gh }}$ & $7.903^{9}$ & $8.653^{\mathrm{et}}$ & $8.333^{a}$ & $8.120^{b}$ \\
\hline 312 Freezer $\left(-12.5^{\circ} \mathrm{C}\right)$ & $6.500^{\mathrm{e}}$ & $6.600^{\mathrm{e}}$ & $6.670^{i}$ & $6.867^{i}$ & $6.937^{i}$ & $6.813^{\mathrm{c}}$ & $6.603^{\mathrm{d}}$ \\
\hline 412 Freezer $\left(-12.5^{\circ} \mathrm{C}\right)$ & $5.767^{9}$ & $5.867^{g}$ & $5.933^{\mathrm{j}}$ & $6.027^{\mathrm{j}}$ & $6.313^{\dagger}$ & $6.573^{i}$ & $6.266^{\mathrm{g}}$ \\
\hline 512 Freezer $\left(-12.5^{\circ} \mathrm{C}\right)$ & $6.400^{\mathrm{et}}$ & $6.600^{\mathrm{e}}$ & $6.697^{\prime}$ & $6.707^{\prime}$ & $6.867^{\prime}$ & $6.630^{\mathrm{d}}$ & $6.496^{\mathrm{e}}$ \\
\hline 311 Fridge $\left(9.5^{\circ} \mathrm{C}\right)$ & $7.433^{\mathrm{d}}$ & $7.600^{d}$ & $8.853^{\text {de }}$ & $10.867^{\mathrm{a}}$ & $10.903^{a}$ & - & - \\
\hline 312 Fridge $\left(9.5^{\circ} \mathrm{C}\right)$ & $6.500^{\mathrm{e}}$ & $6.567^{\mathrm{e}}$ & $8.443^{\dagger}$ & $9.023^{d}$ & $10.333^{b}$ & - & - \\
\hline 412 Fridge $\left(9.5^{\circ} \mathrm{CO}\right)$ & $5.767^{g}$ & $6.233^{\dagger}$ & $7.460^{\mathrm{h}}$ & $7.927^{9}$ & $9.100^{\mathrm{cd}}$ & - & - \\
\hline 512 Fridge $\left(9.5^{\circ} \mathrm{C}\right)$ & $6.400^{\mathrm{ef}}$ & $6.433^{\text {et }}$ & $8.383^{\dagger}$ & $8.857^{\mathrm{de}}$ & $9.393^{c}$ & - & - \\
\hline $311 \operatorname{Room}\left(28.5^{\circ} \mathrm{C}\right)$ & $7.433^{\mathrm{d}}$ & $8.833^{a}$ & - & - & - & - & - \\
\hline $312 \operatorname{Room}\left(28.5^{\circ} \mathrm{C}\right)$ & $6.500^{\mathrm{e}}$ & $8.200^{\mathrm{b}}$ & - & - & - & - & - \\
\hline $412 \operatorname{Room}\left(28.5^{\circ} \mathrm{C}\right)$ & $5.767^{\mathrm{g}}$ & $6.600^{\mathrm{e}}$ & - & - & - & - & - \\
\hline $512 \operatorname{Room}\left(28.5^{\circ} \mathrm{C}\right)$ & $6.400^{\mathrm{ef}}$ & $7.900^{\mathrm{C}}$ & - & - & - & - & - \\
\hline SEM & & 722 & & & 0.1133 & & 0.0096 \\
\hline
\end{tabular}

The interaction between processing methods and storage conditions is shown in Table 8. At 0-5 days' storage, the $\mathrm{pH}$ of the various products at refrigeration condition was lower than products under room storage but higher than products under freezer storage. The snail meat product is better shelf stable under fridge and freezer storage due to lower $\mathrm{pH}$ as product in refrigeration storage had shelf life of 20 days, freezer storage could last 30 days and beyond while room stored products lasted for 6 days. This was also reflected in Table 9.

\section{CONCLUSION}

The various processing methods caused reduction in the moisture content of products particularly oven-drying. The high protein value in seasoned smoke-dried product demonstrated that smoke component has preservative influence because of the polyphenols which has antimicrobial properties. All the seasoned products had low $\mathrm{pH}$ values than the unseasoned product and this could be ascribed to the effect of the seasonings. The $\mathrm{pH}$ of the product under refrigeration condition was lower than product under room storage but higher than product under freezer storage. For extended shelf life and increase in nutritive component of snail meat there should be a combined effect of seasonings, smoke-drying and cold storage.

\section{COMPETING INTERESTS}

Authors have declared that no competing interests exist.

\section{REFERENCES}

1. Onyeike EN, Oguike JU. Influence of heat processing methods on the nutrient composition and lipid characterization of groundnut (Arachis hypogaea) seed pastes. Biokemistri. 2003;15(1):34-43.

2. Ojiako OA, Ogbuji CA, Agha NC, Onwuliri AVA. The proximate, mineral and toxicant composition of four possible food security crops from southern Nigeria. J. Med. Food. 2010;13(5):1203-1209.

3. Iwanegbe I, Igene JO, Emelue GU, Obaroakpo JU. Effect of processing, storage days and storage temperatures on lipid oxidation and palatability processed snail meat products. Asian Food Science Journal. 2019;6(2):1-12.

4. Ezeama CF, Keke E, Nwachukwu E. Influence of brime treatment, drying methods and storage conditions on the microbial quality of freshwater snail (Lanistes libycus) meat. Nig Food J. 2007; 25:101-111.

5. AOAC (Association of Official Analytical Chemists) Official Method of Analysis, $4^{\text {th }}$ Ed; 2000.

6. Okonkwo TM, Anyaene LU. Meat Yield and the effects of curing on the characteristics of snail meat. J. of Tropical Agriculture, Food, Environment and Extension. 2009; 8(1):66-73.

7. Omoyakhi JM, Osinowo OA. Modification of some biochemical activities response to 
transition of giant African land snails. Arhchachatina marginata and Achantina achantina from aestivation to an Active state. Achives of Applied Science Research. 2010;2(3):53-60.

8. Akhter S, Rahaam M, Hossain MM, Hashern MA. Effect of drying as Preservation techniques on nutrient content of beef. J. Bangladesh Agril. Univ. 2009;7(1):163 -168.

9. Iwanegbe I, Obaroakpo JU, Suleiman M. Effect of processing and storage methods on water content and activity of snail meat products. The Nigerian Journal of Agric. And Forrestry. 2018;6(1):59-70.

10. Chima JU, Akobundu ENT. Proximate composition of processed freshwater snail (Pilaovata) meat as affected by salting, fermentation and frying. Journal Agric Environ. 2010;12(2);150 -156.

11. Adegbite JA, Sanni LO, Osinowo OA. Comparative evaluation of chemical and sensory properties of Achatina achatina and Archachatina marginata. Assert an international Journal. Asset Series A. 2006;6(2):1-6.

12. Engman $F N$, Ellis WO, Dzogbefia VP, Yong - Kim M, Abano E, Owusu J. A comparative study of three drying methods for preservation of the giant African snail
(Achatina achatina) meat. African Journal of Food Science. 2012;6(14):392-400.

13. Oduro W, Ellis WO, Oduro I, Tetteh D. Meat yield and quality of selected snail species in Ghana, Journal of Ghana Science Association. 2002;4(2):24-30.

14. Adeola AJ, Adeyemo AI, Ogunjobi JA, Alaye SA, Adelakun KM. Effect of natural and concentrate diets on proximate composition and sensory properties of Giant Land Snail (Archachatina marginata) Meat. Journal of Applied Science in Environment Sanitation. 2010;5(2):185189.

15. Kalio GA, Godfrey AK, Ibisime E. Nutritional and sensory profiling of the African Giant land snail fed commercial type and leaf based diets in a rain-forest ecology. Journal of Food, Agric. Nutri. and Development. 2011;11(5).

16. Wosu LO. Commercial snail farming in West African - A Guide Ap Express Publishers, Nsukka - Nigeria; 2003.

17. Fagbuaro O, Oso JA, Edward JB, Ogunleye RF. Nutritional status of four species of giantland snails. Nigeria J. Zhejiang Univ. Sci. 2006;7(9):686-689.

18. Kiers JL, Van-Laeken AEA, Rombout FM, and Nout MJR. In vitro digestibility of Bacillus fermented soya bean. Int. J. Food Microbial. 2000;60:163 -169.

(c) 2018 Iwanegbe et al.; This is an Open Access article distributed under the terms of the Creative Commons Attribution License (http://creativecommons.org/licenses/by/4.0), which permits unrestricted use, distribution, and reproduction in any medium, provided the original work is properly cited. 